\title{
DIAGNOSTIC REPRODUCIBILITY OF THE ELONGATED STYLOID PROCESS
}

\author{
REPRODUTIBILIDADE DIAGNÓSTICA DO ALONGAMENTO \\ DO PROCESSO ESTILÓIDE
}

\author{
Gulnara SCAF, DDS, MSc, PhD \\ Associate Professor, Department of Oral Diagnosis and Surgery, Araraquara Dental School, State of São Paulo University. \\ Deborah Queiroz de FREITAS, DDS \\ MSc Graduate Student, Oral Radiology, Piracicaba Dental School, University of Campinas. \\ Leonor de Castro Monteiro LOFFREDO, PhD \\ Associate Professor, Department of Social Dentistry, Araraquara Dental School, State of São Paulo University. \\ This paper was presented at the $13^{\text {th }}$ International Congress of DentoMaxilloFacial Radiology, Glasgow, 2001.
}

7 he aim of this study was to estimate the reproducibility related to the presence and to the measurements of
elongated styloid process (ESP), based on panoramic radiographs and the prevalence of ESP. Experimental
design: one hundred sixty six panoramic radiographs were used, from edentulous patients from the Radiology
Clinic files, at Araraquara Dental School, Unesp, during a four-year period. One hundred and twenty one were
female and 45 were male. Two calibrated observers evaluated the radiographs. A caliper was used to measure, in
mm, the ESP from the base of the temporal bone to the tip of the structure. The ESP was considered present when
the measurements were 30mm or more. Kappa statistics (k) and intra-class correlation coefficient (r), were applied
to estimate the reproducibility. The results showed that related to the presence of ESP, the interobserver agreement
was k=0.85. Related to the measurements of ESP, the interobserver agreement was $\mathrm{r}=0.52$. The prevalence of ESP
was estimated in $12.6 \%$. ESP distribution in females was similar to that for males. In conclusion, we found a greater
level of agreement when observers evaluated the presence of ESP than when they did the measurement of ESP. The
prevalence of ESP was $12.6 \%$.

UNITERMS: Radiography, panoramic; Temporal bone; Calcification, physiologic; Reproducibility, prevalence.

\section{INTRODUCTION}

Elongated styloid process (ESP) is being seen more often with the widespread use of panoramic radiographs in dental practice. ${ }^{5,9}$ The ESP and/or the mineralization of the styloid process is considered present if its length equals or exceeds $30 \mathrm{~mm}$ from the temporal bone on the panoramic radiographs. ${ }^{3,5,12}$

Although, the panoramic is the more common projection to detect $\mathrm{ESP}^{2-5,8-10}$, other projections ${ }^{2}$ can be used, such as posteroanterior of mandible, oblique lateral of mandible, axial and cephalometric radiographs. ${ }^{11}$ The panoramic radiograph shows some limitations when it is used to make measurements of $\mathrm{ESP}^{2,5,9}$, such as the superimposition of other skeletal structures that obscures a clear image of the basal part of the complex and the possibility of having linear distortion based on the position of the patient's head in the $\mathrm{x}$-ray machine.

The styloid process is normally a slender, cylindrical bone that arises from the temporal bone in front of the stylomastoid foramen. The attached structures include the stylopharyngeus, the stylohyoid, the styloglossus muscles and the stylohyoid ligament that reaches the hyoid bone. ${ }^{2,5,9}$

Embryologically, the styloid process, the stylohyoid ligament and the lesser cornu of the hyoid bone are developed from the second branchial arch called Reichert's cartilage. Because it is of cartilaginous origin, the ligament has the potential to mineralize. ${ }^{1,5}$

A widespread terminology is found in the literature to express the elongation of styloid process and/or the 
mineralization of stylomandibular or stylohyoid ligament. Some authors consider the calcification of stylohyoid complex the best terminology. ${ }^{2,3,7,8}$

There is a high variability in prevalence studies about ESP. ${ }^{2-5,8-10}$ O Carroll ${ }^{10}$ reported a slight gender predilection for females. But for other authors ${ }^{2-5,8,9}$ equal frequency occurred in both male and female subjects. Some authors related the increasing length of styloid process with age,,$^{4,5,9,10}$ but Correll ${ }^{3}$ could not find substantiate relationship. Omnell, et al. ${ }^{11}$ suggest that ESP starts during childhood and adolescence.

Although the ESP is generally asymptomatic, it can cause atypical facial pain. The facial pain, headache, a sensation of a foreign object lodged in the throat and difficulty in swallowing have been associated with ESP and is known as Eagle's syndrome. . $^{1,3,4,7,10}$

The decision to study edentulous patients was based on the symptoms and complaints presented by these patients, during clinical examinations.

It is sometimes difficult to detect in the panoramic radiographs the point of emergence of the process from the temporal bone because of the superimposed shadow of the mastoid process. ${ }^{4}$ The correct diagnosis of ESP must be made in order to have the real magnitude of its prevalence.

Because of the possibility of ESP being related to atypical facial pain, mainly in edentulous patients, the present investigation has been designed to determine the reproducibility related to the presence and to the measurements of ESP. In addition, if we reach a good level of interobserver agreement in the diagnosis of the ESP, it is interesting to estimate the prevalence of ESP.

\section{MATERIAL AND METHODS}

The sample size was 166 panoramic radiographs of edentulous patients (121 female and 45 male) from the Radiology clinic files, at Araraquara Dental School, Unesp, during a four-year period. The panoramic radiographs were taken with the same $\mathrm{X}$ ray unit Panoramax AX-4CM (Asahi, Kyoto, Japan).

Only those radiographs without errors in patient positioning, exposure or development were included in the study. All radiographs were viewed by two calibrated observers, using a standard view box under reduced room lighting and masks were used in order to prevent extraneous light from reaching their retinas.

In order to minimize bias, the radiographs were read twice by the same observer in two different occasions, independently and under blind conditions.
The interval between the two interpretations was 15 days.

The patient's age and gender were recorded for each radiograph. The length of the ESP was measured from the base of the temporal bone to the tip of the structure. and it was documented if the ESP occurred on one or both sides.

Any elongation of the styloid process and/or mineralization of the stylohyoid ligament measuring $30 \mathrm{~mm}$ or more in length was considered present (Figure 1). We used a caliper (Fowler, Ultra-Call Mark III, Switzerland) to measure the ESP, in $\mathrm{mm}$.

We applied Kappa statistics (k) for interobserver agreement in detecting the ESP and intra-class correlation coefficient ( $r$ ) to verify the interobserver agreement related to the measurements of the ESP. Since the Kappa value was indicative of good agreement at both interpretations, it the prevalence of ESP was estimated among those edentulous patients, related to gender (relative risk $-\mathrm{RR}$ and Chi-square

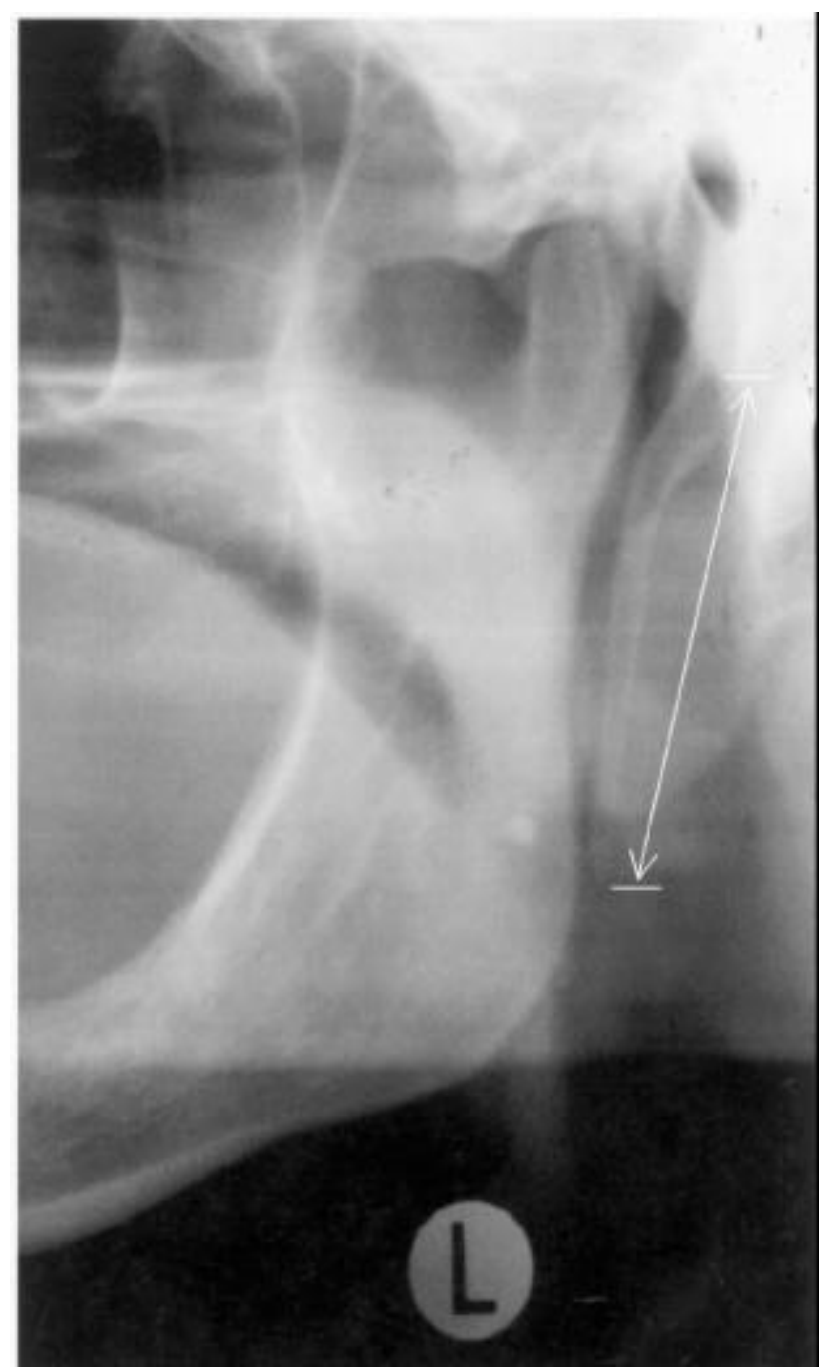

FIGURE 1- Part of panoramic radiograph showing an elongated styloid process, on left side 
test $\left.-\mathrm{c}^{2}\right)$ and to age $\left(\mathrm{c}^{2}\right)$. The significance level was set at $\mathrm{p}$ value $=.05$

\section{RESULTS}

The reproducibility study was performed to check the interobserver agreement.

According to Table 1, the presence of ESP, Kappa value was $\mathrm{k}=0.85$, and showed an excellent interobserver agreement according to the patterns proposed by Landis, Koch. ${ }^{6}$ Related to the measurements, intraclass correlation coefficient was $\mathrm{r}=0.52$, considered moderate.

The prevalence of ESP was estimated at $12.6 \%$ for the total sample.

According to Table 2, there were no significant differences between the two genders.

The majority of these ESP were unilateral (90.5\%) and only $9.5 \%$ were bilateral. Seventy six and two percent occurring on the right side and $14.3 \%$ on the left side .

According to Table 3, age was not significant at $\mathrm{p}$ value $=.05$ but approached this value $(\mathrm{p}=.055)$.

\section{DISCUSSION}

When measurements of ESP are made, there are some difficulties in distinguishing it from the temporal bone on panoramic radiographs. Because of this, the two observers were calibrated before interpreting ESP presence and its measurements, to eliminate probable disagreement on radiographic interpretation.

The interobserver agreement related to the presence of ESP was $\mathrm{k}=0.85$, considered excellent. The interobserver agreement related to the measurements was $r=0.52$, considered moderate. When the two observers did the measurements, agreement was low, which can be explained based on the difficulty of distinguishing ESP from the temporal bone. However, when the two observers detected the presence of ESP the agreement was excellent, because the tip of the ESP is easier to detect than the base of temporal bone.

The only paper that reports ESP considering interobserver agreement, with two examiners using panoramic radiographs, was done by Zaki, et al. ${ }^{12}$. They found an interobserver agreement of 0.86 for the left side and 0.82 for the right side.

The reported prevalence studies on ESP show a wide range. ${ }^{2-5,8-10}$ Correll, et $\mathrm{al}^{3}$ found $18.2 \%$ and Keur, et $\mathrm{al}^{5}$ in a sample of edentulous patients, reported a prevalence of $30.0 \%$. In our study we found a low
TABLE 1- Interobserver agreement related to the presence $(\mathrm{P})$ and to the measurements $(\mathrm{M})$ of elongated styloid process

\begin{tabular}{lll}
\hline Statistic & P & M \\
\hline Kappa & 0.85 & - \\
Intraclass correlation & - & 0.52 \\
\hline
\end{tabular}

Scoring: $0=$ poor $; 0.01-0.2=$ slight; $0.21-0.4=$ fair $; 0.41$ $0.6=$ moderate $; 0.61-0.8=$ substancial; $0.81-1.0=$ excellent

TABLE 2- Prevalence of elongated styloid process (ESP) in percentage (\%) according to gender

\begin{tabular}{llll}
\hline Gender & $\mathbf{n}$ & ESP & $\%$ \\
\hline Male & 45 & 5 & 11.1 \\
Female & 121 & 16 & 13.2 \\
Total & 166 & 21 & 12.6 \\
\hline
\end{tabular}

$R R=0.84 ; c^{2}=0.13(p$ value $=.719)$

TABLE 3- Prevalence of elongated styloid process (ESP) in percentage (\%) according to age

\begin{tabular}{llll}
\hline Age & $\mathbf{n}$ & ESP & $\%$ \\
\hline $20-40$ & 24 & 4 & 16.7 \\
$40-60$ & 88 & 15 & 17.0 \\
$60-80$ & 54 & 2 & 3.7 \\
Total & 166 & 21 & 12.6 \\
\hline
\end{tabular}

$\chi^{2}=5.80 ;(p$ value $=.055)$

prevalence $(12.6 \%)$ that is almost in agreement with the findings of MacDonald-Jankowski ${ }^{8}$ who found $7.8 \%$ for a population of Londoners and $8.6 \%$ for Chinese.

We agree with Ferrario, et al. ${ }^{4}$ about the impossibility of comparing the results from prevalence studies, because the discrepancies in the results are based on different radiographic criteria and samples.

We notice that the occurrence of ESP was similar in females and males, consistent with others authors ${ }^{4,5,11}$. O Carroll ${ }^{10}$ reported a slight predilection for females. 
We found that the majority of ESP was unilateral, located on right side $(76.2 \%)$. On left side it was (14.3\%). Only $9.5 \%$ was bilateral. However, O Carroll $^{10}$, Ferrario, et $\mathrm{al}^{4}$ and Correll, et $\mathrm{al}^{3}$ found the majority of ESP to be bilateral. Probably, the clinical evidence to explain the high prevalence unilaterally can be based on muscle tension originated from occlusal disarrangements.

The majority of the authors ${ }^{4,5,9,10,11}$ found a positive relationship between the presence and/or increasing length of ESP and age. Related to the presence of ESP, we notice that according to age the prevalence was not significant, although the association between ESP and age was in the limit of significance (Table 3). Our results are based on the characteristic of the sample. The edentulous patients from our sample were not so older, how it may be expected. Sixty seven per cent of the total sample was not up to sixty years old.

Although our study did not relate the prevalence of ESP to facial pain, for which multi-causal factors can be responsible, ESP has lead us to consider this fact when we are taking care of adult patients. We suggest a future study on the presence of ESP in symptomatic patients, considering the occlusal disarrangements.

\section{CONCLUSIONS}

We found a greater level of agreement when observers evaluated the presence of ESP than when they did the measurement of ESP.

The prevalence of ESP was $12.6 \%$, and it was similar in both genders .

\section{RESUMO}

O objetivo deste trabalho foi avaliar a reprodutibilidade relacionada à presença e às medidas do alongamento e a prevalência do processo estilóide (APE), utilizando radiografias panorâmicas. Foram utilizadas cento e sessenta e seis radiografias, do arquivo da Clínica de Radiologia, da Faculdade de Odontologia de Araraquara, Unesp, de pacientes desdentados, atendidos num período de quatro anos. Cento e vinte um pacientes eram do gênero feminino e quarenta e cinco do masculino. Dois examinadores calibrados avaliaram as radiografias. Foi utilizado um paquímetro para medir, em mm, o APE da base do osso temporal à extremidade da estrutura. O APE foi considerado presente quando as medidas ultrapassaram $30 \mathrm{~mm}$. A reprodutibilidade foi avaliada utilizando a estatística Kappa (ê) e o coeficiente de correlação intra-classe ( $\tilde{n})$. Os resultados mostraram que a concordância interexaminador foi $\hat{\mathrm{e}}=0,85$, relativa à presença do $\mathrm{APE}$ e $\tilde{\mathrm{n}}=0,52$ relativa às medidas do APE. A prevalência do APE foi 12,6\%. A distribuição do APE no gênero feminino foi semelhante ao masculino. Concluindo, o nível de concordância entre os dois examinadores quanto à presença do APE foi maior do que quando eles mediram o APE. A prevalência do APE foi $12,6 \%$.

UNITERMOS: Radiografia panorâmica; Osso temporal; Calcificação fisiológica, Reprodutibilidade; prevalência.

\section{ACKNOWLEDGEMENTS}

The authors wish to thank $\mathrm{CNPq}^{\prime}$ s fellowships \# 523136/95-1, \# 451337/01-8 , Dr. Elisa E. Macedo for reading the radiographs and $\mathrm{Mr}$. Antonio Medeiros Filho for secretarial assistance.

\section{REFERENCES}

1- Barret AW, Griffiths MJ, Scully C. Osteoarthrosis, the temporamandibular joint and Eagle's syndrome. Oral Surg Oral Med Oral Pathol 1993; 75:273-5.

2- Camarda AJ, Deschamps C, Forest D. Stylohyoid chain ossification: a discussion of etiology (Part. II). Oral Surg Oral Med Oral Pathol 1989; 67:515-20.

3- Correll RW, Jensen JL, Taylor JB, Rhyne RR. Mineralization of the stylohyoid - stylomandibular ligament complex. A radiographic incidence study. Oral Surg Oral Med Oral Pathol 1979; 48:286-91

4- Ferrario VF, Sigurta D, Daddona A, Dalloca L, Miani A, Tafuro F, Sforza C. Calcification of the stylohyoid ligament: Incidence and morphoquantitative evaluations. Oral Surg Oral Med Oral Pathol 1990; 69:524-9.

5- Keur JJ, Campbell JPS, McCarthy JF, Ralph WJ. The clinical significance of the elongated styloid process. Oral Surg Oral Med Oral Pathol 1986; 61:399-404.

6- Landis JR, Koch GG. The measurement of observer agreement for categorical data. Biometrics 1977; 33: 159-74.

7- Langlais RP, Miles DA, Van Dis ML. Elongated and mineralized stylohyoid ligament complex: A proposed classification and report of a case of Eagle's syndrome. Oral Surg Oral Med Oral Pathol 1986; 61:527-32.

8- MacDonald-Jankowski DS. Calcification of the stylohyoid complex in Londoners and Hong Kong Chinese. Dentomaxillofacial Radiol 2001; 30:35-9. 
9- Monsour PA, Young WG. Variability of the styloid process and stylohyoid ligament in panoramic radiographs. Oral Surg Oral Med Oral Pathol 1986; 61:522-6.

10- OCarrol MK. Calcification in the stylohyoid ligament. Oral Surg Oral Med Oral Pathol 1984; 58:617-21.

11- Omnell KAH, Gandhi C, Omnell ML. Ossification of the human stylohyoid ligament. A longitudinal study. Oral Surg Oral Med Oral Pathol Oral Radiol Endod 1998; 85: 226-32.

12-Zaki HS, Greco CM, Rudy TE, Kubinski JA. Elongated styloid process in a temporomandibular disorder sample : prevalence and treatment outcome. J Prosthet Dent 1996; 75: 399-405.

Recebido para publicação em: 14/11/2002

Aceito após reformulações em: 14/04/2003

Correspondence to:

Dr. Gulnara Scaf

Faculdade de Odontologia de Araraquara -

Unesp - Rua Humaitá, 1680

CEP 14801-903 - Araraquara, SP, Brazil.

Phone \# 16 201-6364 (O) 16 222-3285 (H)

Fax \# 16 201-6314

e-mail address: scaf@foar.unesp.br 